\title{
SUGARCANE CULTIVARS RESPONSE TO PLANTING DATE
}

\author{
Bekheet, M.A; S.A.A.M Enan and A.B.A. El-Taib \\ Sugar Crops Res. Inst., Agric. Res. Center, Giza, Egypt
}

\begin{abstract}
Recently, some growers in El-Minia Governorate, Middle Egypt, got used to late planting of sugar cane after wheat or sugar beet. Sugar Crops Research Institute produced many promising varieties of sugarcane among them G.84-47 and Phil.8013. Therefore, it was necessary to study the effect of delaying planting date on vegetative characters, juice quality, cane and sugar yields of these sugar cane varieties. So, two field experiments were conducted at Mallawi Agricultural Research Station, Minia Governorate, including two plant cane crops planted in 2007/2008 and 2008/2009 seasons and their first ratoons grown in 2008/2009 and 2009/2010 seasons. Three sugarcane varieties namely G.T.54-9 (the commercial variety), Phil.8013 and G.84-47 were randomly planted in four replicates, in a randomized complete block design in four dates, i.e. 15 March (the optimum planting date, control), 15 April, 15 May and 15 June. Thereafter, a combined analysis between the sugar cane varieties grown in the four dates was done. Sugarcane was harvested at age of 12 months for the plant cane crops and 10 months for the first ratoons.

The obtained data pointed out that planting dates had a significant effect on stalk height and diameter, total soluble solids, sucrose, purity, sugar recovery, pol. percentages, quality index as well as millable canes and recoverable sugar yields/fed of the plant cane and first ratoon crops. Meanwhile, the tested sugarcane varieties differed significantly in all studied traits, except millable cane yield/fed of the plant cane and first ratoon. Moreover, results of the present work cleared that Phil.8013 variety was the highest affected by delaying planting date.

Under conditions of the present work, planting G.84-47 and/or G.T.54-9 sugarcane varieties on the $15^{\text {th }}$ of March or April is preferable to get the highest cane and sugar yields/fed.
\end{abstract}

Key words: Sugarcane variety, Planting date, Pol \%, TSS \% and Sugar recovery $\%$.

\section{INTRODUCTION}

Sugarcane is the main crop in the world for sugar production. In Egypt, it produced approximately $50.3 \%$ of 1.9 million tons of local sugar production. Sugarcane plantation in Minia Governorate (nearly $38725 \mathrm{fed}$ ) is directed to sugar and treacle production as well as to the fresh use of cane juice (ESST, 2011 and SCC, 2011).

Recently, some sugar cane growers in El-Minia Governorate, Middle Egypt, got used to late planting of sugar cane after wheat or sugar beet harvesting. Sugar Crops Research Institute produced many promising varieties of sugarcane, among them G.84-47, and Phil.8013. Planting of sugarcane in the optimum date is one of the major factors needed for a sufficient vegetative growth season of the crop as well as sugar synthesis and accumulation. Besides, in Egypt, the current recommendation for planting sugarcane is from

Fayoum J. Agric. Res. \& Dev., Vol.25, No.2, July, 2011 
mid-February to mid-March for spring cane. However, some sugarcane growers in Minia Governorate plant sugarcane from March till June. Therefore, it was necessary to study the effect of different planting dates on growth criteria, juice quality, cane and sugar yields of some sugar cane varieties to find out the optimal planting date for them. In this respect, Jhansi and Rao (1996), in India, noticed that cane and sugar yields, sucrose \% and purity $\%$ decreased with the delay in planting date from 15 February to 15 May. They found that cane yield mean ranged from 118.75 ton/ha in cvs. Co 8315 to 92.6 ton/ha in Co 8013. Also, they pointed out that delaying the planting date led to reductions in juice sucrose and cane yield. Meanwhile, Channabasappa et al. (1997) showed that delaying planting decreased cane yield. In the same trend, El-Gergawi and El-Shafai (2000) indicated that delaying planting date from 1 March up to 15 April resulted in a significant reduction in stalk height, diameter as well as cane and sugar yields. Ryan $\boldsymbol{e t}$ al. (2005) found that the optimum sugar yields for the plant-cane crops of $\mathrm{CP}$ 70-321, LHo 83-153 and HoCP 85-845 varieties were obtained with August planting in Louisiana. They added that ratoon sugar yields were not affected by planting date for all other cultivars. Hoy et al. (2006) reported that early (beginning of August) and late (October) planting dates can reduce yield potential in Louisiana, USA. Ahmed et al. (2007) indicated that planting date showed a gradual increase in cane yield with the advance of cane planting date to 15 March in Qena Governorate, Egypt. It gave 51.49 and 50.28 tons/fed in $1^{\text {st }}$ and $2^{\text {nd }}$ seasons, respectively. They added that cane yield decreased significantly and gradually as planting date was delayed from 15 March to 15 May, which may be attributed to the differences of climatic conditions between months.

As for varietals differences, it is well known that sugarcane varieties are completely different in their performance, quality and yields due to great variation in their gene structure. In addition, number of shoots emerged and mortality percentage resulted from the competition among plants until they become millable canes is greatly influenced and dependent on planting date and affects the subsequent crop cycle of sugarcane crop which occupies soil for more than 4-5 growing seasons. In this respect Ahmed (1998) found that G.T.54-9 variety recorded the highest values of brix and sucrose percentages, while G.75-368 gave the highest sugar recovery \%. Abd El-Azez (2008) evaluated some sugarcane varieties namely G.84-47, G.99-103, G.98-28, G.98-88, Phil.8013 and the commercial variety G.T.54-9. He revealed that sugarcane varieties differed significantly in stalk height, stalk diameter, millable cane and recoverable sugar yields. Moreover, the tested varieties differed in quality parameters (TSS\%, purity \% and sugar recovery \%). Sugar cane Phil.8013 and G.99-103 varieties recorded the highest values of millable cane and recoverable sugar yields. In addition, El-Sogheir and Ferweez (2009) tested five sugarcane varieties i.e., G.84-47, G. 99-103, G.98-28, Phil.8013 and G.T.54-9. They indicated that G.84-47 surpassed all tested varieties in quality parameters (TSS \%, purity $\%$ and sugar recovery $\%$ ) and millable cane yield. Abd El-Fattah (2010) examined four sugarcane varieties (G.99-103, G.98-28, Phil.8013 and G.T.54-9). He found that G.99-103 variety ranked the first in stalk height, diameter and weight, while Phil.8013 and G.T.54-9 varieties gave the best values of quality parameters, i.e. TSS \%, purity $\%$ and sugar recovery $\%$.

Fayoum J. Agric. Res. \& Dev., Vol.25, No.2, July, 2011 
SUGARCANE CULTIVARS RESPONSE TO PLANTING DATE....

The present investigation was carried out to study the effect of different planting dates on vegetative traits, juice quality as well as cane and sugar yields of some sugar cane varieties.

\section{MATERIALS AND METHODS}

Two field experiments were conducted at Mallawi Agricultural Research Station, Minia Governorate, Egypt, including two spring plant cane crops planted in 2007/2008 and 2008/2009 seasons and their first ratoons grown in 2008/2009 and 2009/2010. Three sugarcane varieties namely G.T. 54-9 (the commercial variety), Phil.8013 and G. 84-47 were arranged in a randomized complete block design, with four replicates, in four planting dates (15 March, the optimum planting date as a control; 15 April; 15 May and 15 June). The combined analysis between the sugarcane varieties and four planting dates was done. Plot area was $42 \mathrm{~m}^{2}$ (six rows of $100 \mathrm{~cm}$ width and $7 \mathrm{~m}$ length). Dry method of planting was adopted using two drills of three-budded cane cuttings. Nitrogen fertilizer was added as Ammonium Nitrate $(33.5 \% \mathrm{~N})$ at the rate of $210 \mathrm{~kg} / \mathrm{fed}$ in two equal doses as side dressing in cane rows, after full emergence of cane plants and one month later for the plant cane and the first ratoon. Phosphorus fertilizer was added in the form of calcium superphosphate $\left(15.5 \% \mathrm{P}_{2} \mathrm{O}_{5}\right)$ at the rate of $60 \mathrm{~kg} / \mathrm{fed}$, which was broadcasted after ridging in furrows before planting for the plant cane and with the first dose of nitrogen fertilizer for the first ratoons. Potassium fertilizer was added as potassium sulphate $\left(48 \% \mathrm{~K}_{2} \mathrm{O}\right)$ at the rate of $48 \mathrm{~kg} / \mathrm{fed}$ after two months from planting for the plant cane and after full emergence for first ratoons. All the required agricultural practices were done as followed by sugarcane growers in the region. Some chemical and physical properties of the soil of the experimental site were determined before seed bed preparation according to the procedures outlined by Jackson (1967). The physical analysis of the experimental site showed that the soil was silty clay loam. Its chemical analysis cleared that the soil contained 21.10 and $19.35 \mathrm{ppm} \mathrm{N} ; 8.50$ and 7.85 ppm P; 175 and $180 \mathrm{ppm} \mathrm{K}$, with $\mathrm{pH}$ of 8.10 and 8.00, in the $1^{\text {st }}$ and $2^{\text {nd }}$ season, respectively. Temperature degrees during the period of study were recorded.

Table 1: Temperature degrees of the experimental site during the period of study in 2007-2008, 2008-2009 and 2009-2010 seasons.

\begin{tabular}{|c|c|c|c|c|c|c|c|c|}
\hline \multirow{3}{*}{ Month } & \multicolumn{2}{|c|}{2007 season } & \multicolumn{2}{|c|}{2008 season } & \multicolumn{2}{|c|}{2009 season } & \multicolumn{2}{|c|}{2010 season } \\
\hline & \multicolumn{8}{|c|}{$\begin{array}{c}\text { Temperature, }{ }^{0} \mathrm{C} \\
\end{array}$} \\
\hline & Max. & Min. & Max. & Min. & Max. & Min. & Max. & Min. \\
\hline January & - & - & 18.4 & 5.9 & 20.6 & 6.2 & 19.8 & 4.3 \\
\hline February & - & - & 21.6 & 6.7 & 22.4 & 7.3 & 22.0 & 5.6 \\
\hline March & 26.3 & 9.5 & 29.0 & 11.7 & 24.2 & 9.1 & 26.1 & 8.7 \\
\hline April & 31.9 & 13.0 & 32.2 & 14.6 & 30.9 & 14.0 & 31.1 & 12.6 \\
\hline May & 36.3 & 19.2 & 34.4 & 18.4 & 33.3 & 17.8 & 34.9 & 17.0 \\
\hline June & 38.0 & 20.2 & 37.5 & 21.5 & 39.3 & 22.8 & 40.0 & 19.8 \\
\hline July & 37.6 & 21.5 & 36.0 & 21.9 & 38.5 & 24.1 & - & - \\
\hline August & 36.3 & 21.6 & 37.7 & 22.2 & 36.7 & 22.2 & - & - \\
\hline September & 33.0 & 19.7 & 36.2 & 21.3 & 36.1 & 21.4 & - & - \\
\hline October & 32.5 & 18.3 & 30.3 & 16.5 & 33.8 & 19.0 & - & - \\
\hline November & 27.8 & 12.2 & 26.8 & 12.3 & 27.7 & 8.9 & - & - \\
\hline December & 21.5 & 7.6 & 22.6 & 8.8 & 20.8 & 5.2 & - & - \\
\hline
\end{tabular}

Source: Mallawi Meteorological Station, El-Minia, Egypt.

Fayoum J. Agric. Res. \& Dev., Vol.25, No.2, July, 2011 
The recorded data:

At age of 12 months for the plant cane crop and 10 months for the first ratoon, 20 plants of sugarcane from each plot were cut to estimate the following:

1. Vegetative traits:

1.1. Stalk height $(\mathbf{c m})$ : It was measured from soil surface to the top visible dewlap.

1.2. Stalk diameter $(\mathbf{c m})$ : It was measured at the middle part of the stalk.

2. Quality parameters:

2.1. Total soluble solids percentage (TSS \%), which was determined using "Brix hydrometer" standardized at $20^{\circ} \mathrm{C}$ as shown by AOAC (2005).

2.2. Sucrose \%, which was determined using "Sacharemeter" according to AOAC (2005).

2.3. Juice purity \% was estimated according to Satisha $\boldsymbol{e t}$ al. (1996) using the following equation: Purity $\%=$ sucrose $\%$ x $100 /$ TSS $\%$.

2.4. Pol \% of cane stalks, which was calculated using the following equation, after the determination of sucrose $\%$ in the cane juice, according to Satisha et al. (1996). Pol $\%=\{$ Brix $\%-($ Brix $\%$ - sucrose $\%) 0.4\} 0.73$.

2.5. Sugar recovery $\%$, which was calculated using the equation according to the procedures used by the Egyptian Sugar and Integrated Industries Co. as follows:

Sugar recovery $\%=\{\mathrm{Pol} \%-0.8 / \mathrm{Purity} \%$ juice $\mathrm{x}$ Purity $\%$ juice $-40 / 100-$ $60\}$ x 100

2.6. Quality index of cane stalks, which was calculated using the following equation: Quality index = sugar recovery \% / Pol \% x 100

3. Millable cane and recoverable sugar yields:

3.1. Millable cane yield (ton/fed): cane stalks of the four guarded rows were harvested at age of 12 months for the plant cane and 10 months for the first ratoons, topped, cleaned, weighed and cane yield was calculated in ton/fed.

3.2. Recoverable sugar yield (ton/fed), which was estimated according to the following equation reported by Mathur (1981):

Recoverable sugar yield (ton/fed) $=$ millable cane yield (ton/fed) $\mathrm{x}$ sugar recovery $\%$.

The proper statistical analysis of data was done according to Gomez and

Gomez (1984). The differences between means of the studied treatments were compared using least significant difference (LSD) at 5\% level.

\section{RESULTS AND DISCUSSION}

A. Vegetative traits (cane stalk height and diameter):

Data in Table 2 showed a significant and gradual reduction in stalk height and diameter of sugarcane for both the plant cane and first ratoon as planting date was delayed from $15^{\text {th }}$ March up to $15^{\text {th }}$ June. These results may be due to the fact that sugar cane planted in different dates would ripen simultaneously with the gradual decrease in temperature degrees in November, December and January, which means that sugarcane planted latter had shorter effective growth term compared to those planted earlier and hence shorter stalks and thinner diameter. It could be noted from the results that the rate of reduction in stalk height accompanied the delay in planting date was higher than that of stalk diameter for both plant cane and first ratoon. Also, the rate of reduction in stalk height and stalk diameter as a result of delaying planting date was

Fayoum J. Agric. Res. \& Dev., Vol.25, No.2, July, 2011 
higher for plant cane than first ratoon. These results are in harmony with those obtained by El-Gergawi and El-Shafai (2000).

Regarding the evaluated sugarcane varieties, data in Table 2 showed that the tested varieties differed significantly in their stalk height and diameter in both plant cane and first ratoon. Sugarcane G.84-47 variety exhibited general superiority over the other varieties in respect to stalk height, while the commercial variety G.T.54-9 recorded the lowest values of this trait for both plant cane and first ratoon. Meantime, Phil.8013 variety showed a general superiority over the other varieties in stalk diameter, while G.84-47 variety had the lowest value of this trait. The variations among the tested cane varieties in these traits might be due to the action of gene the make-up, which played an important role in plant structure and morphology. These findings are in agreement with those reported by Abd El-Latif (1998); El-Gergawi and El-Shafai (2000) and El-Sogheir and Ferweez (2009), who recorded significant differences among the tested cane varieties in stalk height and diameter.

Data in Table 2 pointed to a significant influence of the interaction between planting dates and sugarcane varieties on stalk height and diameter in the plant and $1^{\text {st }}$ ratoon crops. As for plant height, the results showed that difference in this trait between G.T.54-9 and G.84-47 varieties was insignificant when they were planted on the $15^{\text {th }}$ of April, while the difference between them was significant on the other planting dates. In the $1^{\text {st }}$ ratoon, it was found that the variance between G.T. 54-9 and Phil.8013 varieties in stalk height was insignificant in the earlier planting date. However, the difference between them in this trait was significant in the other planting dates.

Regarding the effect of the interaction between the studied factors on stalk diameter, it was noticed that the difference between Phil.8013 and each of G.T. 54-9 and/or G.84-47 varieties was great and distinguished in the earliest planting date, either in the plant cane or $1^{\text {st }}$ ratoon crops compared to the differences recorded in the other planting dates, pointing to the influence of early planting on this trait. 
Bekheet, M.A; et al.

Table 2: Effect of planting date on stalk height and diameter $(\mathrm{cm})$ for the plant cane and first ratoon of three sugarcane varieties (combined over the two seasons).

\begin{tabular}{|c|c|c|c|c|c|}
\hline \multirow{2}{*}{$\begin{array}{c}\text { Planting } \\
\text { dates } \\
\text { (A) }\end{array}$} & \multirow{2}{*}{$\begin{array}{l}\text { Sugar cane } \\
\text { variety } \\
\text { (B) }\end{array}$} & \multicolumn{2}{|c|}{ Plant cane } & \multicolumn{2}{|c|}{ First ratoon } \\
\hline & & $\begin{array}{l}\text { Stalk height } \\
(\mathrm{cm})\end{array}$ & $\begin{array}{c}\text { Stalk diameter } \\
(\mathrm{cm})\end{array}$ & $\begin{array}{l}\text { Stalk height } \\
(\mathrm{cm})\end{array}$ & $\begin{array}{c}\text { Stalk diameter } \\
(\mathrm{cm})\end{array}$ \\
\hline \multirow{3}{*}{$15 / 3$} & G.T.54-9 & 297.67 & 2.63 & 305.00 & 2.60 \\
\hline & Phil.8013 & 307.00 & 3.07 & 304.00 & 3.02 \\
\hline & G.84-47 & 317.67 & 2.43 & 317.67 & 2.40 \\
\hline \multicolumn{2}{|c|}{ Mean } & 307.45 & 2.71 & 308.89 & 2.67 \\
\hline \multirow{3}{*}{$15 / 4$} & G.T.54-9 & 295.00 & 2.51 & 302.33 & 2.54 \\
\hline & Phil.8013 & 281.67 & 2.94 & 290.33 & 2.90 \\
\hline & G.84-47 & 300.00 & 2.40 & 301.33 & 2.37 \\
\hline \multicolumn{2}{|c|}{ Mean } & 292.22 & 2.62 & 298.00 & 2.60 \\
\hline \multirow{3}{*}{$15 / 5$} & G.T.54-9 & 255.00 & 2.64 & 269.00 & 2.54 \\
\hline & Phil.8013 & 247.67 & 2.84 & 242.00 & 2.77 \\
\hline & G.84-47 & 265.67 & 2.35 & 267.67 & 2.37 \\
\hline \multicolumn{2}{|c|}{ Mean } & 256.11 & 2.61 & 259.56 & 2.56 \\
\hline \multirow{3}{*}{$15 / 6$} & G.T.54-9 & 203.00 & 2.51 & 210.00 & 2.48 \\
\hline & Phil.8013 & 200.00 & 2.81 & 200.67 & 2.74 \\
\hline & G.84-47 & 238.33 & 2.34 & 243.00 & 2.32 \\
\hline \multicolumn{2}{|c|}{ Mean } & 213.78 & 2.55 & 217.89 & 2.51 \\
\hline \multirow{3}{*}{$\begin{array}{c}\text { Average of } \\
\text { varieties }\end{array}$} & G.T.54-9 & 262.67 & 2.57 & 271.58 & 2.54 \\
\hline & Phil.8013 & 259.08 & 2.92 & 259.25 & 2.86 \\
\hline & G.84-47 & 280.42 & 2.38 & 282.42 & 2.37 \\
\hline \multicolumn{2}{|c|}{ Overall mean } & 267.39 & 2.62 & 271.08 & 2.59 \\
\hline \multicolumn{2}{|c|}{ LSD at 0.05 for: } & $\begin{array}{c}\mathrm{A}=4.74 \\
\mathrm{~B}=3.10 \\
\mathrm{AB}=6.21\end{array}$ & $\begin{array}{c}\mathrm{A}=0.05 \\
\mathrm{~B}=0.04 \\
\mathrm{AB}=0.07\end{array}$ & $\begin{array}{c}\mathrm{A}=5.87 \\
\mathrm{~B}=4.52 \\
\mathrm{AB}=7.29\end{array}$ & $\begin{array}{c}\mathrm{A}=0.04 \\
\mathrm{~B}=0.03 \\
\mathrm{AB}=0.06\end{array}$ \\
\hline
\end{tabular}

\section{B. Quality parameters:}

Data in Tables 3-5 showed a significant decrease in quality parameters of sugarcane in terms of TSS $\%$, sucrose $\%$, purity $\%$, sugar recovery $\%$, pol. $\%$ and quality index as planting date was delayed from $15^{\text {th }}$ March up to $15^{\text {th }}$ June for both plant cane and the first ratoon. It could be noted that the rate of reduction in the studied quality traits of cane juice as a result of delaying the planting date was higher in the plant cane than those recorded in the first ratoon. These results may be due to the fact that prolonging the period during which sugarcane plants are exposed to increasing temperature degrees before harvesting during March, April and June as a result of delaying planting date direct plants to retrieve its vegetative growth, which require the analysis of the disaccharide (sucrose) into monosaccharide (glucose and fructose), causing a deterioration in juice quality characteristics. Such effect on quality parameters with delaying planting date was mentioned by Hoy et al. (2006) and Ahmed et al. (2007).

Fayoum J. Agric. Res. \& Dev., Vol.25, No.2, July, 2011 
SUGARCANE CULTIVARS RESPONSE TO PLANTING DATE ....

Table 3: Effect of planting dates on total soluble solids \% (TSS \%) and sugar recovery \% for the plant cane and first ratoon of three sugar cane varieties (combined over the two seasons).

\begin{tabular}{|c|c|c|c|c|c|}
\hline \multirow{2}{*}{$\begin{array}{l}\text { Planting } \\
\text { dates } \\
\text { (A) }\end{array}$} & \multirow{2}{*}{$\begin{array}{l}\text { Sugar cane } \\
\text { variety } \\
\text { (B) }\end{array}$} & \multicolumn{2}{|c|}{ Plant cane } & \multicolumn{2}{|c|}{ First ratoon } \\
\hline & & TSS \% & $\begin{array}{c}\text { Sugar recovery } \\
\%\end{array}$ & TSS \% & $\begin{array}{c}\text { Sugar } \\
\text { recovery } \%\end{array}$ \\
\hline \multirow{3}{*}{$15 / 3$} & G.T.54-9 & 21.90 & 12.78 & 21.73 & 12.46 \\
\hline & Phil.8013 & 22.47 & 13.35 & 22.03 & 12.85 \\
\hline & G.84-47 & 22.33 & 13.15 & 22.03 & 12.66 \\
\hline \multicolumn{2}{|c|}{ Mean } & 22.23 & 13.09 & 21.93 & 12.65 \\
\hline \multirow{3}{*}{$15 / 4$} & G.T.54-9 & 22.50 & 12.96 & 21.97 & 12.47 \\
\hline & Phil.8013 & 22.17 & 12.97 & 21.93 & 12.78 \\
\hline & G.84-47 & 22.37 & 12.99 & 22.33 & 12.69 \\
\hline \multicolumn{2}{|c|}{ Mean } & 22.34 & 12.97 & 22.08 & 12.64 \\
\hline \multirow{3}{*}{$15 / 5$} & G.T.54-9 & 20.47 & 11.37 & 20.27 & 11.05 \\
\hline & Phil.8013 & 21.80 & 12.01 & 21.93 & 12.14 \\
\hline & G. $84-47$ & 21.77 & 11.97 & 22.03 & 12.16 \\
\hline \multicolumn{2}{|c|}{ Mean } & 21.34 & 11.78 & 21.41 & 11.79 \\
\hline \multirow{3}{*}{$15 / 6$} & G.T.54-9 & 19.73 & 10.33 & 19.20 & 10.16 \\
\hline & Phil.8013 & 21.27 & 11.52 & 21.10 & 11.40 \\
\hline & G.84-47 & 21.33 & 11.59 & 21.07 & 11.34 \\
\hline \multicolumn{2}{|c|}{ Mean } & 20.78 & 11.15 & 20.46 & 10.97 \\
\hline \multirow{3}{*}{$\begin{array}{l}\text { Average of } \\
\text { varieties }\end{array}$} & G.T.54-9 & 21.15 & 11.86 & 20.79 & 11.54 \\
\hline & Phil.8013 & 21.93 & 12.46 & 21.75 & 12.29 \\
\hline & G.84-47 & 21.95 & 12.43 & 21.87 & 12.21 \\
\hline \multicolumn{2}{|c|}{ Overall mean } & 21.68 & 12.25 & 21.47 & 12.01 \\
\hline \multicolumn{2}{|c|}{ LSD at 0.05 for: } & $\begin{array}{c}\mathrm{A}=0.14 \\
\mathrm{~B}=0.11 \\
\mathrm{AB}=0.21\end{array}$ & $\begin{array}{c}\mathrm{A}=0.16 \\
\mathrm{~B}=0.08 \\
\mathrm{AB}=0.17\end{array}$ & $\begin{array}{c}\mathrm{A}=0.15 \\
\mathrm{~B}=0.10 \\
\mathrm{AB}=0.20\end{array}$ & $\begin{array}{c}\mathrm{A}=0.17 \\
\mathrm{~B}=0.07 \\
\mathrm{AB}=0.19\end{array}$ \\
\hline
\end{tabular}

Data in Tables 3-5 showed that the tested sugarcane varieties recorded significantly different values of TSS $\%$, sucrose $\%$, purity $\%$, sugar recovery $\%$, pol $\%$ and quality index. These results were true in the plant cane and the first ratoon. The maximum values of sucrose $\%$, purity $\%$, sugar recovery $\%$, and quality index were recorded by Phil.8013 variety, while, the highest values of TSS \% and pol \% were recorded by G.84-47 variety in the plant cane and first ratoon. Moreover, the differences between Phil.8013 and G.84-47 varieties in the studied quality traits were mostly insignificant in the plant and $1^{\text {st }}$ ratoon cane crops. These findings might be due to genetic variation among the studied varieties for these traits. These results are in harmony with those obtained by Abd El-Latif (1998); Abd El-Azez (2008) and El-Sogheir and Ferweez (2009). 
Bekheet, M.A; et al.

Table 4: Effect of planting dates on sucrose \% and purity $\%$ for the plant cane and first ratoon of three sugar cane varieties (combined over the two seasons).

\begin{tabular}{|c|c|c|c|c|c|}
\hline \multirow{2}{*}{$\begin{array}{l}\text { Planting } \\
\text { dates } \\
\text { (A) } \\
\end{array}$} & \multirow{2}{*}{$\begin{array}{c}\text { Sugar cane } \\
\text { variety } \\
\text { (B) }\end{array}$} & \multicolumn{2}{|c|}{ Plant cane } & \multicolumn{2}{|c|}{ First ratoon } \\
\hline & & Sucrose \% & Purity \% & Sucrose \% & Purity \% \\
\hline \multirow{3}{*}{$15 / 3$} & G.T.54-9 & 18.87 & 86.43 & 18.48 & 85.03 \\
\hline & Phil.8013 & 19.63 & 87.37 & 18.97 & 86.11 \\
\hline & G.84-47 & 19.38 & 86.78 & 18.75 & 85.10 \\
\hline \multicolumn{2}{|c|}{ Mean } & 19.30 & 86.86 & 18.73 & 85.42 \\
\hline \multirow{3}{*}{$15 / 4$} & G.T.54-9 & 19.17 & 85.21 & 18.52 & 84.31 \\
\hline & Phil.8013 & 19.14 & 86.35 & 18.89 & 86.13 \\
\hline & G.84-47 & 19.18 & 85.75 & 18.84 & 84.35 \\
\hline \multicolumn{2}{|c|}{ Mean } & 19.16 & 85.77 & 18.75 & 84.93 \\
\hline \multirow{3}{*}{$15 / 5$} & G.T.54-9 & 17.02 & 83.18 & 16.63 & 82.07 \\
\hline & Phil.8013 & 17.82 & 81.73 & 18.14 & 82.71 \\
\hline & G.84-47 & 17.88 & 82.31 & 18.19 & 82.54 \\
\hline \multicolumn{2}{|c|}{ Mean } & 17.57 & 82.41 & 17.65 & 82.44 \\
\hline \multirow{3}{*}{$15 / 6$} & G.T.54-9 & 15.73 & 79.72 & 15.45 & 80.49 \\
\hline & Phil.8013 & 17.33 & 81.32 & 17.16 & 81.32 \\
\hline & G.84-47 & 17.43 & 81.69 & 17.09 & 81.12 \\
\hline \multicolumn{2}{|c|}{ Mean } & 16.83 & 80.96 & 16.57 & 80.98 \\
\hline \multirow{3}{*}{$\begin{array}{c}\text { Average of } \\
\text { varieties }\end{array}$} & G.T.54-9 & 17.70 & 83.64 & 17.27 & 82.98 \\
\hline & Phil.8013 & 18.48 & 84.23 & 18.29 & 84.07 \\
\hline & G.84-47 & 18.47 & 84.13 & 18.22 & 83.28 \\
\hline \multicolumn{2}{|c|}{ Overall mean } & 18.22 & 84.00 & 17.93 & 83.44 \\
\hline \multicolumn{2}{|c|}{ LSD at 0.05 for: } & $\begin{array}{c}\mathrm{A}=0.18 \\
\mathrm{~B}=0.10 \\
\mathrm{AB}=0.21\end{array}$ & $\begin{array}{c}\mathrm{A}=0.55 \\
\mathrm{~B}=0.28 \\
\mathrm{AB}=0.56\end{array}$ & $\begin{array}{c}\mathrm{A}=0.16 \\
\mathrm{~B}=0.10 \\
\mathrm{AB}=0.20\end{array}$ & $\begin{array}{c}\mathrm{A}=0.49 \\
\mathrm{~B}=0.25 \\
\mathrm{AB}=0.51\end{array}$ \\
\hline
\end{tabular}

The interaction between planting date and varieties had a significant effect on quality parameters of sugarcane in terms of TSS and sugar recovery percentages of the plant cane and first ratoon as shown in Table 3. The results showed that the differences between G.84-47 and Phil.8013 varieties in TSS \% were insignificant when sugarcane as plant cane and first ratoon were grown on $15^{\text {th }}$ of March, $15^{\text {th }}$ May and $15^{\text {th }}$ June. Meanwhile, the differences between G.T.54-9 and G.84-47 varieties and between Phil.8013 and G.84-47 varieties were insignificant when sugarcane as a plant cane grown on $15^{\text {th }}$ April, while the differences between G.T.54-9 and G.84-47 varieties and between Phil.8013 and G.84-47 varieties reached the level of significance when sugarcane as a first ratoon grown under $15^{\text {th }}$ April, the differences between G.T.54-9 and G.84-47 varieties and between (G.T.54-9, G.84-47 varieties) were insignificant when sugarcane as a plant cane and first ratoon grown on $15^{\text {th }}$ May and $15^{\text {th }}$ June.

Sucrose and purity percentages in Table 4 were significantly affected by the interaction between planting dates and sugarcane varieties. The results

Fayoum J. Agric. Res. \& Dev., Vol.25, No.2, July, 2011 
SUGARCANE CULTIVARS RESPONSE TO PLANTING DATE....

obtained that the differences between G.84-47 and G.T.54-9 and between G.T.54-9 and Phil.8013 varieties on sucrose \% were insignificant when sugarcane as a plant cane grown on $15^{\text {th }}$ of April. Meantime, the differences reached the level of significance when sugarcane as a first ratoon grown under $15^{\text {th }}$ of April. On the other hand the differences between G.84-47 and G.T.54-9 and between Phil.8013 and G.84-47 varieties in purity \% were insignificant when sugarcane as a first ratoon grown under $15^{\text {th }}$ May. Meanwhile, the differences reached the level of significance when sugarcane as a plant cane grown under $15^{\text {th }}$ of May.

Table 5: Effect of planting date on pol. \% and quality index of three sugar cane varieties for plant cane and first ratoon (combined over the two seasons).

\begin{tabular}{|c|c|c|c|c|c|}
\hline \multirow{2}{*}{$\begin{array}{l}\text { Planting } \\
\text { dates }(\mathrm{A})\end{array}$} & \multirow{2}{*}{$\begin{array}{l}\text { Sugar cane } \\
\text { variety }(B)\end{array}$} & \multicolumn{2}{|c|}{ Plant cane } & \multicolumn{2}{|c|}{ First ratoon } \\
\hline & & Pol \% & Quality index & Pol \% & Quality index \\
\hline \multirow{3}{*}{$15 / 3$} & G.T.54-9 & 15.10 & 84.60 & 14.92 & 83.53 \\
\hline & Phil.8013 & 15.57 & 85.72 & 15.19 & 84.55 \\
\hline & G.84-47 & 15.44 & 85.19 & 15.13 & 83.67 \\
\hline \multicolumn{2}{|c|}{ Mean } & 15.37 & 85.17 & 15.08 & 83.92 \\
\hline \multirow{3}{*}{$15 / 4$} & G.T.54-9 & 15.45 & 83.84 & 15.03 & 82.95 \\
\hline & Phil.8013 & 15.30 & 84.79 & 15.12 & 84.49 \\
\hline & G.84-47 & 15.40 & 84.35 & 15.28 & 83.03 \\
\hline \multicolumn{2}{|c|}{ Mean } & 15.38 & 84.33 & 15.14 & 83.49 \\
\hline \multirow{3}{*}{$15 / 5$} & G.T.54-9 & 13.94 & 81.57 & 13.74 & 80.47 \\
\hline & Phil.8013 & 14.75 & 81.42 & 14.90 & 81.46 \\
\hline & G.84-47 & 14.77 & 81.04 & 14.96 & 81.30 \\
\hline \multicolumn{2}{|c|}{ Mean } & 14.49 & 81.34 & 14.53 & 81.08 \\
\hline \multirow{3}{*}{$15 / 6$} & G.T.54-9 & 13.24 & 77.99 & 12.92 & 78.67 \\
\hline & Phil.8013 & 14.38 & 80.10 & 14.26 & 79.92 \\
\hline & G.84-47 & 14.43 & 80.32 & 14.22 & 79.75 \\
\hline \multicolumn{2}{|c|}{ Mean } & 14.02 & 79.47 & 13.80 & 79.45 \\
\hline \multirow{3}{*}{$\begin{array}{l}\text { Average of } \\
\text { varieties }\end{array}$} & G.T.54-9 & 14.43 & 82.00 & 14.15 & 81.40 \\
\hline & Phil.8013 & 15.00 & 83.01 & 14.87 & 82.61 \\
\hline & G.84-47 & 15.01 & 82.72 & 14.90 & 81.94 \\
\hline \multicolumn{2}{|c|}{ Overall mean } & 14.81 & 82.58 & 14.64 & 81.98 \\
\hline \multicolumn{2}{|c|}{ LSD at 0.05 for: } & $\begin{array}{c}\mathrm{A}=0.11 \\
\mathrm{~B}=0.08 \\
\mathrm{AB}=0.15\end{array}$ & $\begin{array}{c}\mathrm{A}=0.68 \quad \mathrm{~B}=0.30 \\
\mathrm{AB}=0.60\end{array}$ & $\begin{array}{c}\mathrm{A}=0.10 \\
\mathrm{~B}=0.08 \\
\mathrm{AB}=0.14\end{array}$ & $\begin{array}{c}\mathrm{A}=0.63 \\
\mathrm{~B}=0.28 \\
\mathrm{AB}=0.56\end{array}$ \\
\hline
\end{tabular}

The interaction in Table 5 between planting dates and varieties had a significant effect on pol\% and quality index as a plant cane and first ratoon. The results showed that the differences between G.84-47 and Phil.8013 varieties in quality index\% were insignificant when sugarcane as plant cane grown on $15^{\text {th }}$ of March. Meanwhile, the differences between the same varieties reached the level of significance when sugarcane as a first ratoon grown under $15^{\text {th }}$ March. Meantime, the differences between G.T.54-9 and

Fayoum J. Agric. Res. \& Dev., Vol.25, No.2, July, 2011 
G.84-47 varieties and G.84-47 and Phil.8013 varieties in pol\% reached the level of significance when sugarcane as a first ratoon grown under $15^{\text {th }}$ April. On the other hand the differences between Phil.8013, G.84-47 varieties on quality index were insignificant when sugarcane as a plant cane $15^{\text {th }}$ of April. While, reached the level of significance when sugarcane as a first ratoon grown under $15^{\text {th }}$ April.

\section{Millable cane and recoverable sugar yields:}

Results in Table 6 clarified a significant decrease in millable cane and recoverable sugar yields of both plant cane and first ratoon as planting date was delayed from $15^{\text {th }}$ March to $15^{\text {th }}$ June. Delaying planting date from $15^{\text {th }}$ March to $15^{\text {th }}$ April, $15^{\text {th }}$ May or $15^{\text {th }}$ June led to decreasing millable cane yields by $3.61,18.01$ and 27.58 tons/fed for plant cane, corresponding to 3.40 , 12.86 and 22.61 tons/fed for the first ratoon. Similarly, recoverable sugar yield decreased by $0.54,2.85$ and 4.17 tons/fed, for plant cane by $0.43,1.99$ and 3.44 tons/fed respectively. It could be noted that the rate of reduction in millable cane and recoverable sugar yields of sugarcane resulted from delaying the planting date was higher for plant cane than first ratoon. Such effect was mentioned by Jhansi and Rao (1996) and Ahmed et al. (2007).

Results in Table 6 showed that the tested varieties varied significantly in recoverable sugar yield and insignificantly in millable cane yield of sugar cane for the plant cane and first ratoon. The highest values of recoverable sugar yield were recorded by Phil.8013 variety (5.57 tons/fed) for the plant cane and G.84-47 variety (5.80 tons/fed) for first ratoon. The difference between Phil.8013 and G.84-47 in this trait was insignificant for the plant cane. These results are in harmony with those obtained by Abd El-Latif (1998); Abd El-Azez (2008) and El-Sogheir and Ferweez (2009).

The interaction between planting date and varieties had a significant effect on millable cane and recoverable sugar yields/fed for both plant cane and first ratoon as shown in Table 6 . The results showed that the differences between G.84-47 and G.T.54-9 varieties on millable cane yield/fed were insignificant when sugarcane as plant cane grown on $15^{\text {th }}$ of March and $15^{\text {th }}$ April. Meanwhile, the differences between the same varieties reached the level of significance when sugarcane as a first ratoon grown under $15^{\text {th }}$ March and $15^{\text {th }}$ April. On the other hand, the differences between G.T.54-9 and G.84-47 varieties on recoverable sugar yield/fed were insignificant when sugarcane as a first ratoon grown under $15^{\text {th }}$ March. Meanwhile, those differences reached the level of significance when sugarcane as a plant cane grown under $15^{\text {th }}$ March. Also, the differences between G.T.54-9 and G.84-47 varieties on recoverable sugar yield/fed were insignificant when sugarcane as plant cane grown on $15^{\text {th }}$ of April, while that differences reached the level of significance when sugarcane as a first ratoon grown under $15^{\text {th }}$ April. Effect of planting date on productivity and quality of the studied sugarcane varieties was the lowest with G.84-47 variety than the other ones for both plant cane and first ratoon crops. Moreover, results of the present work pointed out that Phil.8013 was the highest variety affected by delay planting date. So, planting dates of sugarcane G.T. 54-9 variety (the commercial variety) beside G.84-47 variety on the $15^{\text {th }}$ March or April is preferable under conditions of the present study.

Fayoum J. Agric. Res. \& Dev., Vol.25, No.2, July, 2011 
SUGARCANE CULTIVARS RESPONSE TO PLANTING DATE ....

Table 6: Effect of planting dates on millable cane and recoverable sugar yields (ton/fed) for the plant cane and first ratoon of three sugar cane varieties (combined over the two seasons).

\begin{tabular}{|c|c|c|c|c|c|}
\hline \multirow[b]{2}{*}{$\begin{array}{l}\text { Planting } \\
\text { dates } \\
\text { (A) }\end{array}$} & \multirow[b]{2}{*}{$\begin{array}{l}\text { Sugar cane } \\
\text { variety } \\
\text { (B) }\end{array}$} & \multicolumn{2}{|c|}{\begin{tabular}{|c|} 
Plant cane \\
\end{tabular}} & \multicolumn{2}{|c|}{$\begin{array}{l}\text { First ratoon } \\
\end{array}$} \\
\hline & & \begin{tabular}{|c|}
$\begin{array}{c}\text { Millable cane } \\
\text { yield } \\
\text { (ton/fed) }\end{array}$ \\
\end{tabular} & $\begin{array}{c}\text { Recoverable } \\
\text { sugar yield } \\
\text { (ton/fed)) }\end{array}$ & $\begin{array}{c}\text { Millable cane } \\
\begin{array}{c}\text { yield } \\
\text { ton/fed })\end{array}\end{array}$ & $\begin{array}{c}\text { Recoverable } \\
\text { sugar yield } \\
\text { (ton/fed)) }\end{array}$ \\
\hline \multirow{3}{*}{$15 / 3$} & G.T.54-9 & 53.90 & 6.89 & 58.82 & 7.33 \\
\hline & Phil.8013 & 59.90 & 8.00 & 50.27 & 6.46 \\
\hline & G.84-47 & 54.20 & 7.13 & 57.30 & 7.25 \\
\hline \multicolumn{2}{|c|}{ Mean } & 56.00 & 7.34 & 55.46 & 7.01 \\
\hline \multirow{3}{*}{$15 / 4$} & G.T.54-9 & 52.50 & 6.80 & 56.53 & 7.05 \\
\hline & Phil.8013 & 53.00 & 6.87 & 45.94 & 5.87 \\
\hline & G.84-47 & 51.67 & 6.71 & 53.70 & 6.82 \\
\hline \multicolumn{2}{|c|}{ Mean } & 52.39 & 6.80 & 52.06 & 6.58 \\
\hline \multirow{3}{*}{$15 / 5$} & G.T.54-9 & 38.90 & 4.42 & 43.93 & 4.86 \\
\hline & Phil.8013 & 35.90 & 4.37 & 40.67 & 4.94 \\
\hline & G.84-47 & 39.17 & 4.69 & 43.20 & 5.26 \\
\hline \multicolumn{2}{|c|}{ Mean } & 37.99 & 4.49 & 42.60 & 5.02 \\
\hline \multirow{3}{*}{$15 / 6$} & G.T.54-9 & 29.43 & 3.04 & 34.20 & 3.47 \\
\hline & Phil.8013 & 26.34 & 3.03 & 30.06 & 3.36 \\
\hline & G.84-47 & 29.50 & 3.42 & 34.30 & 3.89 \\
\hline \multicolumn{2}{|c|}{ Mean } & 28.42 & 3.17 & 32.85 & 3.57 \\
\hline \multirow{3}{*}{$\begin{array}{l}\text { Average } \\
\text { of } \\
\text { varieties }\end{array}$} & G.T.54-9 & 43.68 & 5.29 & 48.37 & 5.68 \\
\hline & Phil.8013 & 43.78 & 5.57 & 41.73 & 5.16 \\
\hline & G.84-47 & 43.63 & 5.49 & 47.13 & 5.80 \\
\hline \multicolumn{2}{|c|}{ Overall mean } & 43.70 & 5.45 & 45.74 & 5.55 \\
\hline \multicolumn{2}{|c|}{ LSD at 0.05 for: } & $\begin{array}{c}\mathrm{A}=0.45 \\
\mathrm{~B}=\mathrm{Ns} \\
\mathrm{AB}=1.24\end{array}$ & $\begin{array}{c}\mathrm{A}=0.08 \\
\mathrm{~B}=0.09 \\
\mathrm{AB}=0.18\end{array}$ & $\begin{array}{c}\mathrm{A}=0.65 \\
\mathrm{~B}=\mathrm{Ns} \\
\mathrm{AB}=1.17\end{array}$ & $\begin{array}{c}\mathrm{A}=0.10 \\
\mathrm{~B}=0.12 \\
\mathrm{AB}=0.20\end{array}$ \\
\hline
\end{tabular}

REFERENCES

Abd El-Azez, Y.M. (2008). Evaluation of some new sugarcane varieties as affected by harvesting dates under Middle and Upper Egypt conditions. M.Sc. Thesis, Agron. Dept., Fac. Agric., Minia Univ. Egypt.

Abd El-Fattah, H.A. (2010). Response of some sugarcane varieties to different planting densities. M.Sc. Thesis, Fac. Agric., Cairo Univ., Egypt.

Abd El-Latif, F.A. (1998). Performance of some sugarcane varieties grown under different row spacing. J. Agric. Sci. Mansoura Univ. 23 (7): 3041-3051.

Ahmed, A.Z. (1998). Evaluation of some sugarcane varieties under nitrogen fertilization levels and seeding rates. Ph.D. Thesis, Fac. Agric., Minia Univ., Egypt.

Ahmed, A.Z.; K.S. El-Sogheir and N.M.S. Shalaby (2007). Performance of some sugar cane verities at different planting dates. African Crop Sci., Conf. Proc., (8): 161-172

AOAC (2005). Association of Official Analytical Chemists. Official methods of analysis, $18^{\text {th }} \mathrm{Ed}$. AOAC International, Washington D.C., USA.

Channabasappa, K.S; M.D. Kumar; B.G.M. Reddy and S.G. Patil (1997). Effect of varieties, planting dates and harvesting period on yield and quality of sugarcane. Karnataka J. Agric. Sci. 10 (1): 19-24.

Fayoum J. Agric. Res. \& Dev., Vol.25, No.2, July, 2011 
El-Gergawi, A.S.S. and A.M.A. El-Shafai (2000). Yield and quality of some sugarcane varieties as affected by planting date. J. Agric. Sci. Mansoura Univ. 25 (7): 3753-3760.

El-Sogheir, K.S. and H. Ferweez (2009). Optimum harvesting age of some promising sugarcane genotypes grown under different nitrogen fertilizer levels. Egypt J. Appl. Sci., 24 (3):195-214.

ESST (2011). Thirty-four Annal Conf. Egypt. Soc. of Sugar Technol. Giza, Egypt. factors as influenced by the planting time. Indian Sugar 46(11), 883-888.

Gomez, K.A. and A.A. Gomez (1984). Statistical Procedures for Agricultural Research. $2^{\text {nd }}$ Ed. John Willey and Sons, New York, pp.680.

Hoy, J.W; A.E. Arcencaux and C.F. Savario (2006). Effects of date and rate of billet planting on sugar cane yield. Journal American Society Sugar Cane Technologists, 26: 116-124.

Jackson, M.L. (1967). Soil Chemical Analysis. Prentice-Hall, Inc., Englewood Cliffs, NJ, USA.

Jhansi, K. and Rao, B.R. (1996). Evaluation of promising varieties of sugar cane for shoot borer and internodes borer under different dates of planting. Cooperative Sugar, 27 (9): 675-679.

Mathur, R.B. (1981). Handbook of Cane Sugar Technology. Oxford \& IBH Publishing Co.

Ryan, P.V; E.P. Richard; D.D. Garrison; E.O. Dufrene and T.L. Tew (2005). Sugar cane cultivar response to planting date. J. Amer. Soc. Sugar Cane Technol., 25: 78-89.

Satisha, G.C; M. Krishnappa and K. Srikanth (1996). Input of sulphur on yield and quality of sugarcane. Indian Sugar 45 (9): 397-401.

SCC (2011). Sugar Crops Council. Annual Report, Ministry of Agriculture and land Reclamation, Egypt, (In Arabic).

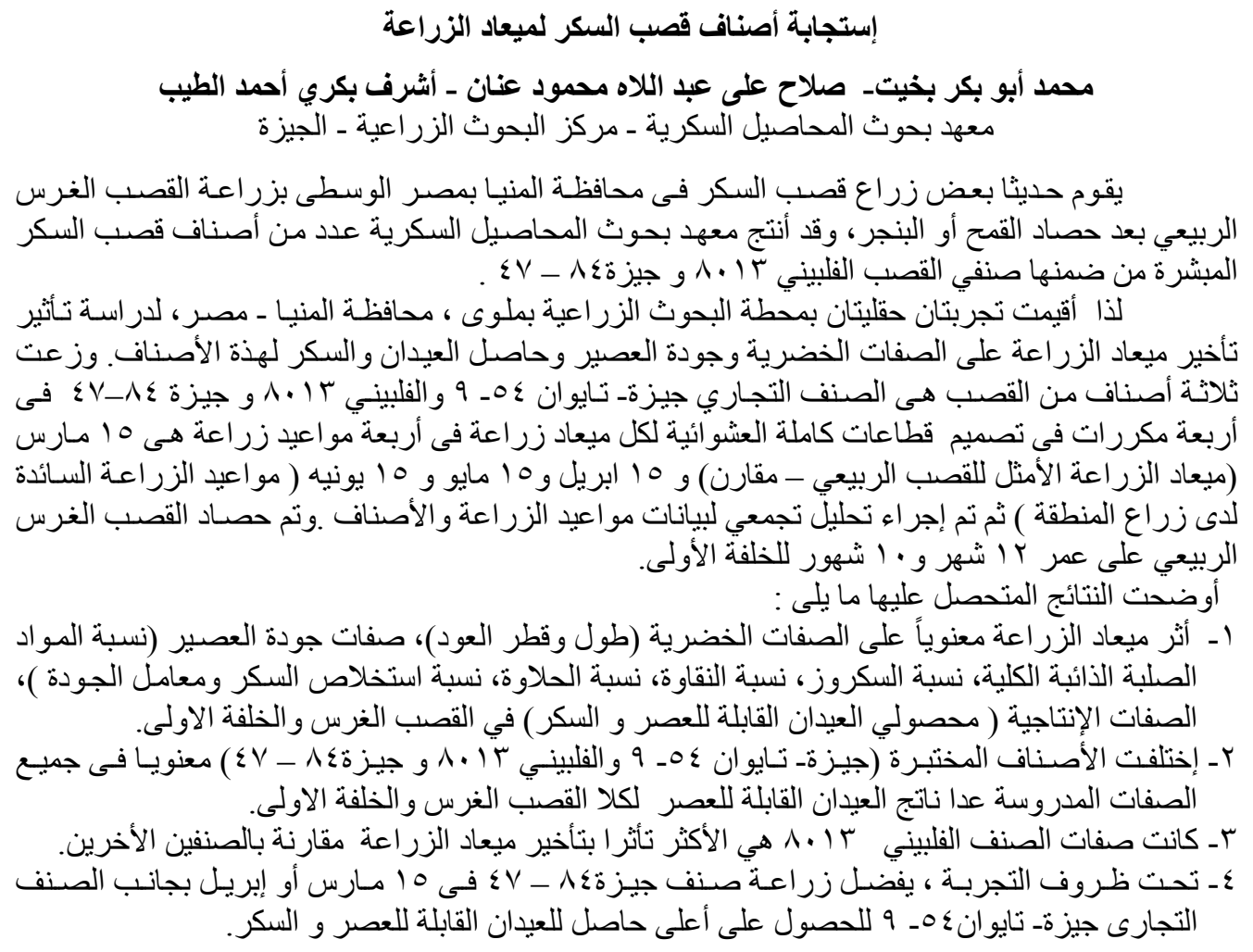

Fayoum J. Agric. Res. \& Dev., Vol.25, No.2, July, 2011 